$11-8-2018$

\title{
Local Strategies for Economic Survival in Touristically Volatile Times: An Indonesian Case Study of Microvendors, Gendered Cultural Practices, and Resilience
}

Kathleen M. Adams

Loyola University Chicago, kadams@luc.edu

Follow this and additional works at: https://ecommons.luc.edu/anthropology_facpubs

Part of the Anthropology Commons

\section{Recommended Citation}

Adams, Kathleen M.. Local Strategies for Economic Survival in Touristically Volatile Times: An Indonesian Case Study of Microvendors, Gendered Cultural Practices, and Resilience. Tourism, Culture, and Communication, 18, 4: 287-301, 2018. Retrieved from Loyola eCommons, Anthropology: Faculty Publications and Other Works, http://dx.doi.org/10.3727/109830418X15369281878422

This Article is brought to you for free and open access by the Faculty Publications and Other Works by Department at Loyola eCommons. It has been accepted for inclusion in Anthropology: Faculty Publications and Other Works by an authorized administrator of Loyola eCommons. For more information, please contact ecommons@luc.edu. (c) $($ ) $९($

This work is licensed under a Creative Commons Attribution-Noncommercial-No Derivative Works 3.0 License. (c) Cognizant, LLC. 2018 


\title{
LOCAL STRATEGIES FOR ECONOMIC SURVIVAL IN TOURISTICALLY VOLATILE TIMES: AN INDONESIAN CASE STUDY OF MICROVENDORS, GENDERED CULTURAL PRACTICES, AND RESILIENCE
}

\author{
KATHLEEN M. ADAMS \\ Loyola University Chicago, Chicago, IL, USA
}

\begin{abstract}
This article utilizes a qualitative ethnographic approach to examine the economic survival strategies pursued by Indonesian souvenir artisans and handicraft microvendors in touristically turbulent times. Resilience-oriented approaches have offered promising frameworks for understanding regions', destinations', and communities' capacities to adjust and adapt to challenges: this article complements these broader approaches by offering a fine-grained analysis of individual strategies for finding creative solutions to the economic challenges thrust upon them. My approach melds a constructivist approach accentuating local peoples' creative responses with gender-aware and practice-oriented approaches. These findings draw from data collected over three decades of ethnographic research in the Toraja highlands of Sulawesi, Indonesia.
\end{abstract}

Key words: Handicrafts; Resilience; Gender; Indonesia

Introduction

As mounting natural and human-induced disasters render international tourism increasingly volatile, local microentrepreneurs in established tourist destinations experience income unpredictability and economic devastation all the more frequently. This is especially true in Indonesia, where natural and human-induced disasters such as Bali's currently simmering volcano, Java's destructive 2006 earthquake, a devastating 2004 tsunami strike on Sumatra's coast, SARs outbreaks, political tumult, and terrorist bombings of hotels and tourist-oriented nightclubs have prompted major ebbs in tourism in recent years (Henderson, 2003; Hitchcock, 2010; Hitchcock \& Putra, 2007; Kuo, Chen, Tseng, Ju, \& Huang, 2008). This article centers on a theme that has preoccupied many Indonesian handicraft artisans and small-scale tourist vendors for the past two decades: the challenge of how to stay afloat when tourist buyers vanish. This is an issue salient not only to hinterland Indonesian handicraft artists and souvenir vendors, but to ethnic minorities in other parts of the world who toil in 
the realm of what Nelson Graburn (1976) termed "ethnic and tourist arts."

Drawing on over 30 years of ethnographic research, this article offers a qualitative examination of the economic survival strategies and tactics pursued by Indonesian souvenir artisans and tourism handicraft microvendors in touristically tumultuous times. In recent years, we have seen a burgeoning interest in tourism scholarship on resilience, a core concern of this article (cf. Bec, McLennan, \& Moyle, 2016; Cheer \& Lew, 2017; Orchiston, Prayag, \& Brown, 2016). Various formulations of resilience-oriented approaches have been advanced as tantalizing theoretical frameworks for understanding destinations' capacities to adjust and adapt to challenges, be they incremental disturbances or monumental natural disasters. Much of this promising work is either conceptual and theoretical, or entails case studies of resilience at the level of regions or communities (Bec et al., 2016; Cochrane, 2010; M. Hall, Prayag, \& Amore, 2018; Strickland-Munro, Allison, \& Moore, 2010). However, as several tourism scholars note, there are far fewer fine-grained studies of the resilience of individuals in destination communities, be they artisans, tourism microentrepreneurs, or local residents whose livelihoods are tethered to the tourist economy (Lew, 2014; Prayag, 2017). ${ }^{1}$ This article answers Girish Prayag's (2017) recent call for studies offering direct analysis of the resilience-building strategies and projects pursued by individual tourism stakeholders, and the networks and forms of capital drawn upon by community members to navigate the increasingly unpredictable ebbs and flows of tourism-derived revenues.

Likewise, although gender has gained traction as a topic in tourism research over the past 15 years, and a growing segment of tourism scholar have turned their lenses to address gendered aspects of tourism practices (cf. Aitchison, 2009; Ghodsee, 2005; Pritchard, Morgan, Ateljevic, \& Harris, 2007), we have yet to see extensive scholarship offering gendered analyses of the interrelations between tourism, microentrepreneurship, and resilience. As a recent Annals of Tourism Research state-of-the-field article suggests, we need to be still more attuned to the often-muted gender dynamics that permeate all aspects of tourism (Figueroa-Domecq, Pritchard, SegoviaPérez, Morgan, \& Villacé-Molinero, 2015). As the authors assessed, "tourism enquiry has been surprisingly gender-blind and reluctant to engage gender-aware frameworks in comparison to cognate disciplines" (p. 88). Although some scholars have begun to analyze the interlinkages between small-scale tourism entrepreneurship, resilience, and gender (cf. Bakas, 2017; Taylor, 2017), additional ethnographic studies will enable planners and policy makers to better understand the ways in which gender factors into models for postcrisis community and individual resilience in tourist destinations. This case study seeks to foster a better understanding of the ties between tourist artisans/ microvendors, gendered cultural practices, and resilience.

\section{Theoretical Background}

This article embraces a qualitative ethnographic approach, in order to foreground the culturally informed understandings and logic undergirding locals' strategies for navigating their predicaments. That is, I aim to highlight how local people whose lives are entwined with tourism make sense of dramatic changes in their world, draw on different types of resources at their disposal, and attempt to find creative solutions to the economic challenges thrust upon them. My analysis melds a constructivist approach (e.g., Bruner 2005), accentuating tourates' creative responses, with gender-aware perspective (cf. Aitchison, 2005) and practiceoriented approaches (e.g., Bourdieu, 1977; de Certeau, 1984).

In spotlighting local people's often improvised strategies for economic survival in touristically tumultuous times, my approach shares terrain with Ed Bruner's (1993) constructivist approach to tourism, which emphasizes the creative ways in which individuals navigate the dynamic worlds in which they live. As he writes, "People construct culture as they go along, and as they respond to life's contingencies" (p. 326). To underscore the creative agency of locals involved in the tourism sector, I utilize Andrew Causey's (2003) term tourate to refer to local people in a tourist destination who interact directly with tourists. Causey's term offers an important corrective to earlier terms (such 
as "hosts”), which 1) do not differentiate between locals who routinely interact with tourists and those who do not, and which 2) suggest that locals are passive recipients of tourists rather than active agents in these encounters.

Also central to my analysis is a practice-oriented approach that acknowledges varied structural constraints on individuals' agency, while recognizing individuals' "capacity for invention and improvisation” (Bourdieu, 1990, p. 13). Tourates' ability to implement creative solutions to economic challenges is always constrained by life circumstances, including access to various forms of capital, as well as sometimes immutable aspects of identity (e.g., ethnic, gender, class, or age). Here, de Certeau's (1984) notion of “making do" (p. 29) is relevant. As paraphrased by Walter Little (2008) in his study of Maya handicraft vendors, "making do" refers to the strategies and tactics used by those with little economic or political power to "make the best of unfavorable conditions" (p. 87). In the Indonesian cases presented here, many of the strategies embraced by artisans and tourism microvendors entail exercising creativity in finding new markets for their goods, or using minimal resources to develop new products that enable slow and steady progress towards economic stability.

Bourdieu's $(1977,1984)$ ideas about social, economic, and cultural capital are also relevant here. Bourdieu expanded our understanding of capital, extending it beyond the financial realm ("economic capital”). For Bourdieu, "social capital” refers to social networks, informal and formal group memberships, and trusted contacts that serve as resources and can help propel one towards success. ${ }^{2}$ In turn, "cultural capital" refers to expertise, skills, and specialized knowledge acquired largely through education (but also through long-term exposure to tourists, as will be seen here), that constitute yet another type of resource and can facilitate social mobility. These three types of capital are interconnected, with social capital and cultural capital generally enabling the amassing of economic capital, although possession of economic capital does not necessarily equate to possession of cultural capital or to the ability to accrue social capital (Bourdieu, 1986). As will be seen in the cases presented here, Torajan artisans and tourism microentrepreneurs draw on these varied forms of capital, to the extent their circumstances allow, as they navigate to stay afloat in economically challenging times.

A recent study of small tourism business owners in Yogyakarta, Indonesia by Ferguson, Dahles, and Prabawa (2017) suggested that while Bourdieuan ideas of capital are important for understanding how some entrepreneurs make more successful economic recoveries than others following tourism crises, an appreciation of the workings of "bounded solidarity" is also needed. As their study outlines, Portes and Sensenbrenner's (1993) idea of "bounded solidarity" enables us to appreciate the ways in which social networks can either "exert leveling pressures on successful individuals to redistribute wealth, instead of reinvesting it in economic ventures” (pp. 173-174). Ferguson et al.'s corrective fosters a more nuanced understanding of why some tourism microentrepreneurs with extensive social capital may achieve less economic resilience than others in the wake of tourism crises. Their observations merit consideration, as well.

Finally, as alluded to earlier, yet another theoretical thread running through this article concerns gender. As advocated by various scholars in recent years (cf. D. Hall, Swain, \& Kinnaird, 2003), this study embraces a gender-aware framework. Such a framework entails an appreciation of the fact that tourism is always superimposed on local gender ideologies, that is, locally defined gendered skills, orientations, practices, and relations. A subtheme of this article concerns the ways in which gendered cultural practices, including gendered knowledge, have enabled some individuals and families to get by in times when tourism arrivals have plummeted. Whereas in some locales, gendered institutions can create obstacles to achieving economic resilience, in the case of my research locale the opposite appears to be more common: women's culturally defined concerns, skills, and activities have provided the tools to forge new economic niches for themselves that encompass (and also extend beyond) the now routinely fickle tourist market.

As Fiona Bakas (2017) underscored, a critical feminist approach to understanding community resilience also necessitates unpacking the gendered ways in which microentrepreneurs interpret their recovery goals. Her study of Greek tourism entrepreneurs' postcrisis recovery efforts found that 
classically "feminine" caretaker ideals structured female Greek handicraft tourism entrepreneurs visions of their efforts as altruistically oriented towards the community's recovery; personal profit was downplayed as a key motive. Her study suggests yet another way in which a gender-aware framework bears relevance for understanding individual and community resilience.

Before turning to examine my research findings, I offer background on the research methodologies employed as well as on the ethnographic context of the research.

\section{Methods}

This study employed a mixed-methods approach centering on qualitative research methodologies (Bernard, 2006). My primary means of data collection was long-term participant observation in the ethnic tourism destination known as the Toraja highlands of Sulawesi, Indonesia. This research was initiated during an 18-month period of ethnographic fieldwork in 1984 and continuing through the summer of 2017 via periodic field research immersions, ranging in time from several weeks to several months. During these periods I resided with a Toraja family in a village frequented by both domestic and international tourists, as well as local handicraft vendors. I selected the village for several reasons. First, it was the original and mostfrequently visited tourist destination in the region, due to its fame as both a significant cultural site (featuring traditional architecture and burial cliffs) and as a location for observing local woodworkers and purchasing carved souvenirs. Second, this village was situated $4 \mathrm{~km}$ from a regional market town and tourist hotel hub, and thus I was able to extend my research activities to this tourist hub where I conducted posttour interviews with tourists and guides, and interviewed hotel employees, tourist café and gallery owners, as well as town-based souvenir store owners and crafts-sellers in the town's bustling marketplace.

My long-term participant observation entailed apprenticing myself to local tourist-oriented carvers, assisting and observing microentrepreneurs in their transactions with tourists, participating in guidetraining workshops, accompanying tourists on tours, partaking in village-based rituals and a village-based international music festival that drew both locals and tourists, and engaging in formal and informal community events. In keeping with ethnographic methodology, observations and insights derived from these activities were recorded daily in field notes, coded, and periodically analyzed to identify emergent themes pertaining to key research questions.

Although some have critiqued ethnographic research methods as too specific to be replicated or applied generally (Adler \& Adler, 1994, cited in Hollinshead, 2004), this approach (particularly participant observation) has been shown to be especially effective at unearthing local peoples' perceptions regarding changes, challenges, and triumphs, and thus was well-suited for this study (Ellen, 1984; Pelto, 2017). Local voicesparticularly those of disempowered minority groups impacted by cultural tourism - are notoriously difficult to access via classic survey methods and questionnaire-based interviews. Reluctance to be candid with short-term researchers in tandem with power imbalances can compromise the validity of other research methodologies. However, long-term participant observation enables researchers to earn the trust of those whose perceptions and attitudes we strive to understand (Adams, 2012). As Stroma Cole (2004) noted in discussing her adaptation of ethnographic research methods to study local perceptions of tourism in Eastern Indonesia, "spontaneous, indoor fireside chats were a more successful technique than attempting to carry out questionnaire-based interviews . . . [and] disclosed information on topics that were not openly discussed at other times” (pp. 295-296).

This research also drew on a series of face-toface, open-ended interviews with Toraja handicraft makers, souvenir microentrepreneurs, tourists, and local government officials whose responsibilities intersected with tourism and/or handicraft development. Interviewees were selected via a purposive sampling strategy. Although broader generalizations drawn from purposive sampling can be problematic, this research strategy enables one to target interviewees whose backgrounds, activities, and concerns are likely to generate richer insights into the issues at the core of a particular study (Bernard, 2006).

I supplemented this qualitative ethnographic research with photographic documentation of 
artisans and microentrepreneurs at work, and critical discourse analysis of tourates' narratives about their endeavors (Fairclough, 1995). Critical discourse analysis' premise is that "certain discourses are more powerful than others [and that these dynamics] can be revealed in the grammatical, semantic, and visual construction of texts and images" (Waterton, 2009, p. 46). This methodology offered an important lens for analyzing strategies embraced by some Toraja microvendors and artisans when international tourist visits evaporated.

\section{Tourism, Gender, and Craft Production in the Toraja Highlands}

The Sa'dan Toraja are a predominantly Christian minority group of over 1,000,000 whose homeland is in the highlands of South Sulawesi. In precolonial times, Toraja society was hierarchically stratified, with aristocrats, commoners, and slaves. Although slavery has long been eradicated, and there is some fluidity to the Toraja system of social stratification, today rank remains a key dimension of inequality in Toraja society. Rank translates roughly into ritualsocial prominence and into property ownership, with aristocrats generally owning larger tracts of land than those of lower ranks. Although many Torajans lacking land-based resources have migrated throughout Indonesia and beyond in search of economic opportunities (Aditjondro, 2010), those remaining in the homeland have traditionally worked in rice, coffee, and subsistence farming, or as small business employees and civil servants.

In contrast to rank, gender is a relatively unmarked category and does not translate into fixed hierarchies (Waterson, 2009). Although rural Toraja families tend towards a gendered division of labor (which also manifests in ritual duties), with women more frequently engaged in the practical responsibilities of child rearing and domestic tasks, Toraja women are well represented in microbusinesses (e.g., snack and handicraft selling) and in civil service. In addition, compared to many other groups, Torajans are progressive when it comes to female educational and professional pursuits. Women's realization of leadership and educational goals is perhaps hindered only by economic constraints and pragmatic "pressures" to start families at relatively younger ages (Waterson, 2009).
Within Indonesia and in the anthropological world, Torajans are famed for their elaborate funeral rituals, haunting mortuary sculptures, and stately traditional houses adorned with incised motifs. Although the region was listed in Indonesia's second tourism development plan (1974-1978) and adventure travelers have been making the bonejarring, 9-hr bus trip to the Toraja highlands since the late 1970s, it was not until the 1980s, after the Indonesian government began promoting the region as the "next destination after Bali," that larger-scale domestic and international tourism began to flourish (Adams, 2006). Whereas in 1972 only 650 foreign tourists visited the Toraja highlands, by tourism's heyday in the mid-1990s the region was hosting 59,388 foreign tourists and 176,949 domestic tourists annually (Adams, 2006).

As tourist arrivals increased in the 1980s and 1990s, growing numbers of Torajans residing around the urban tourist hub of Rantepao or near frequently visited villages began to reorient at least some of their activities towards this new source of revenue. In this era of thriving tourism, local surveys record over 2,000 handicraft-producing households in what was then Tana Toraja Regency (Morrell, 2005, p. 25). ${ }^{3}$ In the hills southeast of Rantepao where I based my research, many households supplemented their farming activities by manufacturing souvenirs. The tourist-oriented products they produced were largely dictated by gender (although there were some exceptions).

Males engaged in producing souvenir wall plaques, suitcase-sized traditional houses, and miniature mortuary sculptures, as well as trays and other carved decorative items designed for the tourist market (see Fig. 1). Some of these men had previous experience in carpentry, crafting wooden artifacts such as funeral biers, ancestral houses, and effigies, for local, traditional purposes. As tourism blossomed, they branched out into the tourist souvenir market. In the 1980s and 1990s, some of these male souvenir carvers toiled in informal, loosely organized carving cooperatives, where they shared carving techniques and skills with one another, as well as insights into what tourists desired (cultural capital). These cooperatives drew tourists hoping to photograph carvers in action and thus served as effective points of sale (economic capital), since foreign tourists, in particular, found it appealing to 


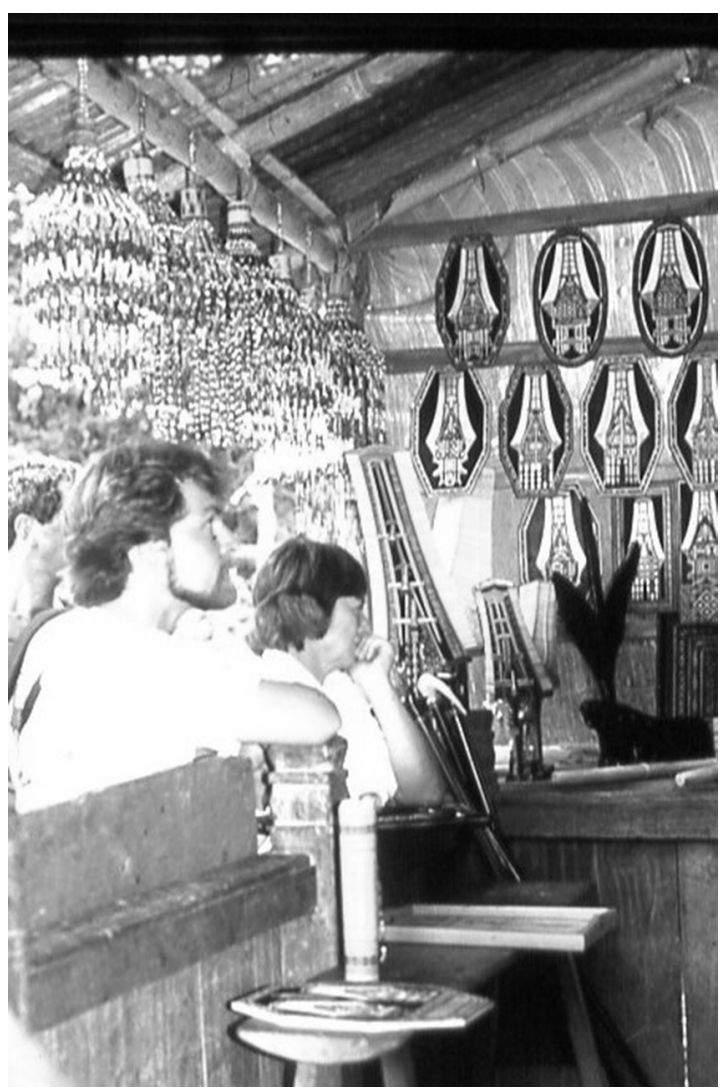

Figure 1. Carvings sculpted by male carvers for sale to tourists at Ke'te' Kesu village in the mid-1980s. Beaded lampshades produced by females hang from the rafters (photo by author).

buy directly from carvers with whom they had interacted. These informal carving cooperatives also offered male carvers companionship, and informal networks of friends and kin with whom they shared not only cigarettes and humor-laced conversations but also work-related resources, such as paint and knives. In short, the informal carving groups that arose in the 1980s and 1990s provided a form of social capital for male souvenir woodworkers.

Other males worked on their own, often moving between subsistence farming activities and souvenir carving on any given day. Although they might tutor their sons in the art of handicraft production in the slower hours of the day, generally these men were solo operators: on market day they would make their way down the hillsides, sometimes selling their carvings to tourist vendors in the tourist site of Ke'te' Kesu, other times selling to the souvenir shops or at the market in town. When tourism slowed to a crawl, many of these independent carvers simply shifted all of their energies back to farming. ${ }^{4}$

In the 1980s and 1990s, a number of the women residing in the poorer hillside hamlets in this area wove handicraft production into their daily routines of subsistence farming on small sloped plots, and household and infant care duties. In this region of the Toraja highlands, most of the women involved in handicraft production crafted souvenirs from tree seeds and beads, and occasionally bamboo. In the early afternoon hours, when the sun grew too hot for other tasks, or during monsoonal rains, these women toiled in the airy spaces under their elevated homes or rice barns, patiently stringing tree seeds (and sometimes beads) into an array of tourist-oriented handicrafts, ranging from decorative door curtains, lampshades, necklaces, and traditional-styled Toraja dance skirts. Often, they multitasked, attending to infants cradled in slings or keeping an eye on a nearby toddler, as they threaded beads or burned designs into tiny bamboo key chains. As other scholars have observed, women's involvement in tourism-related income generating activities is often compatible with household and childcare duties (cf. Bras \& Dahles, 1999).

Very few women engaged in carving. Although women, especially daughters and wives of carvers might help by embellishing their fathers' or husbands' works with paint, generally they are not seen as naturally skilled with knives. (When I apprenticed myself to a Toraja handicraft carver in the mid-1980s, my efforts prompted much teasing by the other male carvers in his cooperative.) However, by the mid- to late-1990s, some younger women (often the daughters of landless agricultural laborers and part-time house and souvenir carvers) in a couple poorer hamlets were trying their luck as full-time carvers, hewing mostly small souvenirs such as wooden and bamboo key chains and occasionally embellished wooden trays: for some, these efforts were paying off in modest ways, while still impoverished, the souvenirs enabled small household improvements (Morrell, 2005). In northern Toraja regions (beyond the scope of this study), the women's realm of handicraft production differs yet again, with women producing weavings on backstrap looms. Their products range from relatively simple, inexpensive souvenir tablecloths and wall 
hangings to finely woven ikat sarongs for ritual and higher-end tourist markets. In short, touristoriented handicraft production was (and remains) largely gendered. Likewise, handicraft production is also bifurcated in terms of markets, in that some products are oriented towards tourists and others towards local markets.

Starting in the late 1990s tourist arrivals in the Toraja highlands began to plummet, following the Indonesian economic crisis (krismon), anti-Chinese rioting in Jakarta, and interethnic/religious violence elsewhere in Indonesia. The subsequent 2002 and 2005 Bali bombings, the Iraq war, Southeast Asian SARS scare, outbreaks of Avian influenza in Indonesia, earthquakes, tsunamis, eruptions of violence between Christians and Muslims in the neighboring Central Sulawesi region of Poso, and the global economic recession all took further tolls on tourism to the area. ${ }^{5}$ Since that time, due in part to the local government's aggressive promotion of return migrant festival tourism, music festival tourism, marathons, and film fêtes, tourist arrival figures have made intermittent recoveries. In 2014 (the most recent year of published statistics that distinguish domestic and international tourists), the area received 71,432 domestic tourists and 41,058 foreign tourists (Bureau of Statistics, 2015). And in 2016, the Toraja highlands received a total of 112,628 tourists. These figures indicate tourism's gradual recovery in the region, but remain significantly lower than the mid-1990s peak tourism era (when some 200,000 domestic tourists and over 50,000 foreign tourists were arriving annually). During these years of erratic tourist arrival figures, Toraja artisans and small-scale tourism vendors drew on various strategies and tactics for "making do" (de Certeau, 1984).

Some handicraft vendors added soft drinks, snacks, sunglasses, and cigarettes to their inventories-items they could sell to fellow villagers in touristically slow times. Those who had enough capital replaced the wood carvings that once dominated their shelves with T-shirts and sarongs, which garner an enduring local market. Still others closed up shop and returned to farming or out-migrated. ${ }^{6}$ Likewise, in this period, a number of carving collectives shuttered their doors. However, a few groups of former souvenir-oriented carvers and collectives were able to survive and thrive.
The extent to which Toraja tourates were able to creatively address the challenges they faced and leverage other noneconomic forms of capital enabled some to achieve greater degrees of economic resilience than others, In the pages that follow, I present several ethnographic examples that help illustrate the varied paths pursued by Toraja tourates as they attempt to overcome the unpredictability of tourism revenues characterizing the past 20 years. Because gender sometimes factors into the paths pursued, one case focuses on a male tourate and two others on female tourates. My emphasis is on successful cases, as these offer potential resilience roadmaps that might be successfully adapted elsewhere.

Example 1: "We No Longer Carve for Tourists, But for Our Own Toraja People”: Artistic Involution and the Cultivation of New (Old) Markets

As their souvenirs gathered dust in the slow years of the late 1990s and early 2000s, some tourist art stall owners embraced economic survival strategies that entailed channeling their energies back into their own pretourism markets. In many cases, this involved extra time and effort, longer work hours, and the cultivation of more distant markets. Clifford Geertz (1963) famously developed the concept of “agricultural involution” to describe a situation where the ever-increasing demands of Dutch colonialism in tandem with population growth on Java resulted in all the more intensive peasant labor efforts in the rice fields, rather than a radical change. Geertz's concept of agricultural involution offers an apt lens for understanding the dynamics involved in the paths followed by some of these struggling tourist art stall owners and carvers. These cases might be best understood as involving what we might term "artistic involution."

Several imaginative carvers drew on their social capital and cultural knowledge (cultural capital) to cultivate new, more reliable markets for their carvings. In keeping with Geertz's idea of cultural involution, these handicraft carvers' strategies entail "artistic involution.” One founder of a tourist carving atelier in Ke'te’ Kesu, Pak Tandi ${ }^{7}$, was particularly adept at navigating the ebbs and flows of the unpredictable tourist market. The aristocratic son of a ritually prominent elder and local 
politician, Pak Tandi had the advantages of a wide social network and more economic security than most carvers. Not only did he own rice fields, but as a younger man in the 1980s, he was already widely recognized for his aesthetic gifts and he and his friends were frequently hired to orchestrate elaborate decorations for Toraja rituals. After his father's death in 1985, Pak Tandi gradually took on greater ritual responsibilities in the community, officiating at funerals and becoming widely recognized and sought after for his knowledge of Toraja cultural heritage. In short, as he matured, he amassed greater political capital (good will and the trust of the community and political figures). As tourism was booming in the early 1990s, Pak Tandi and his wife erected an unassuming home and carving workshop on a hillock overlooking a small parking lot at the entrance to the muchvisited traditional Toraja village of Ke'te' Kesu'. The workshop functioned as a collective and microbusiness, and most days a couple local carvers could be seen chiseling wood in the open air workshop, which invariably drew tourist attention and sales.

In the 1990s, Pak Tandi and his brother became increasingly concerned about younger Torajans who were returning home from schooling or temporary labor in distant cities and were unable to find jobs in their homeland: some of these young men were kin, while others were fellow community members. Pak Tandi and his brother worried that these young unemployed males might fall into gambling and petty crime. Pak Tandi came to envision his souvenir carving atelier as a place for these young men to find training, income, and camaraderie. Here, we should note that Pak Tandi's conceptualization of his tourism enterprise as a means of providing for not only himself and his family, but for his community contrasts with research on gender and entrepreneurship elsewhere. This body of research suggests that male interpretations of entrepreneurship generally stress increased individual profit whereas female interpretations tend to emphasize community resilience in keeping with "feminine subjectivities of caring” (e.g., Bakas, 2017, p. 69). As there is evidence that at least a few other Toraja carving collective leaders also interpret their microentrepreneurship in terms of both individual and collective well-being (e.g., Adams, 2006), it is worth underscoring that claims regarding broad gendered patterns in tourism entrepreneurship and resilience need to be tempered with attention to cultural variables.

Soon Pak Tandi's atelier was not only producing mementos to sell to visiting tourists but also taking bulk orders for souvenirs and decorative Toraja-styled architectural panels for Toraja-owned enterprises elsewhere. His wife helped run the shop which included a small refreshment stand where guides frequently passed time while awaiting their charges as they explored the traditional village. In short, Pak Tandi's strategic location at the entrance to this much-toured village further augmented his social networks, as guides who had come to appreciate his charisma, humor, and knowledge steered visiting dignitaries and researchers towards him. ${ }^{8}$ Ultimately, these ties yielded an affiliation with the Provincial Museum in Makassar, an invitation to assemble an entourage of carvers to travel to Japan to erect a traditional rice barn for a museum, and national commendation as a "hero" of cultural preservation and tourist art development.

In the late 1990s and early 2000s, when tourist arrivals slowed to a trickle, Pak Tandi realized his predominantly tourism-oriented carving workshop could not survive. He found himself contemplating the ancient, carved sarcophagi in the cliffs behind his hamlet, fancifully shaped like pigs and sailing vessels, some embellished with incised traditional motifs, and suddenly recognized an untapped market. Soon thereafter, he transformed his tourist carving workshop into an atelier specializing in finely sculpted coffins with designs mined from these ancient Toraja burial objects, as well as wall panels and furniture incised with traditional designs, all aimed at the local and migrant Toraja market (see Fig. 2).

In part due to his social networks, local fame and the skill of his atelier carvers, Pak Tandi's traditional-styled sculpted coffins quickly became de rigueur for local Torajan funerals. However, there were additional factors at play: to fully understand Pak Tandi's success we also need to appreciate the ways in which tourism and out-migration figure into shifting Toraja tastes and mortuary practices. As noted earlier, land and job scarcity in the highlands prompted a first major wave of 


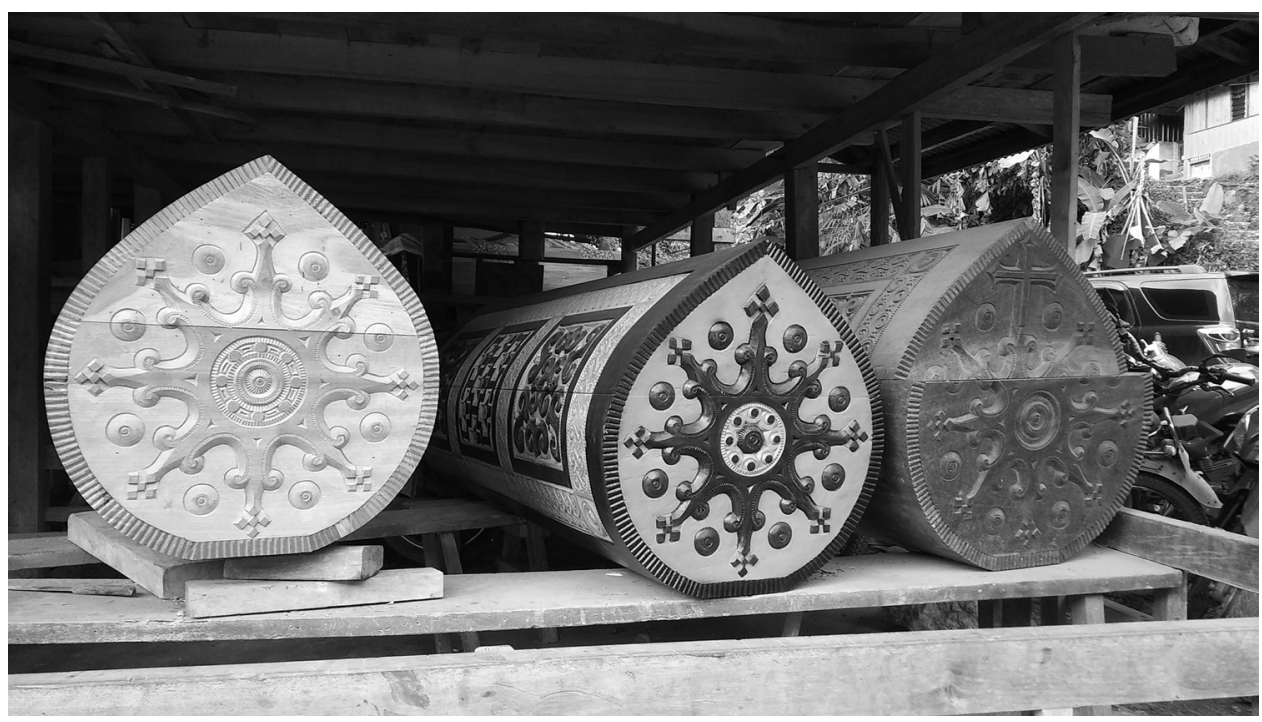

Figure 2. New, traditional-styled coffins in production at Pak Tandi's carving cooperative in 2017 (photo by author).

Torajan out-migration in the 1970s, and out-migration in pursuit of employment and educational opportunities continue to the present day. Migrant remittances have contributed to tremendous inflation in the cost and scale of funeral rituals, as the more successful first-generation migrants channel their familial status-enhancement efforts into funding ever-more dramatic, pageantry-filled funeral rituals in their homeland (Volkman, 1985). These dynamics have produced a thriving local market for distinctive funeral-related carvings, ranging from coffins to carved biers. In addition, whereas Torajans tended to prefer conventional coffins in the 1970s and early 1980s (as older, traditional-styled coffins were, for many, stigmatized as being "backwards"), tourism in the 1980s and 1990s fueled a new-found Toraja appreciation of their ancestral cultural riches (Adams, 2006). By the 1990s, many local and returning migrant Torajans involved in funeral planning were actively seeking coffins and other funeral accouterments that conveyed pride in their heritage. Thus, two factors enabled the rebirth of a local market for stylized coffins that had previously been moribund: migrants' remittances fueled additional funeral expenditures, and several decades of tourism prompted new-found Toraja pride in heritage. In addition, many successful migrants construct second homes for their families in the Toraja highlands, embellishing these homes with furniture, panels, and terrace ceilings incised with typical Toraja motifs. Thus, when tourism was evaporating, Pak Tandi could successfully channel his atelier's efforts into this emerging local market. As Pak Tandi proudly told me in 2012, "We no longer carve for tourists, but for our own Toraja people. And the pay is good-even if I had an MA or a Ph.D., I probably wouldn't be making as much!”

It is worth underscoring that Pak Tandi's reorientation of his atelier away from the unpredictable tourism market and towards the more reliable and profitable local market not only bolstered his own personal income, but it has provided employment and a degree of security for handicraft carvers from his community. Whereas a tourism-oriented carver in 2017 might spend a full day sculpting a single tray in the hope of selling it for IDR 80,000 (US\$5.88), the former handicraft carvers in Pak Tandi's workshop now earn almost twice as much (IDR 150,000, or US\$11.03) in a single day of carving heritage inspired objects for the Toraja market.

Pak Tandi sometimes couches his workshop endeavors in heartfelt language that stresses the importance of not only individual but community well-being. However, this case of economic resilience in the context of waning tourism clearly echoes patterns reported in other studies addressing 
community tourism-based development: these studies found elite kin groups' social capital enabled "capture” of indigenous tourism income-enhancement projects (See Schilcher, 2007; Taylor, 2017). Yet, Pak Tandi's social capital alone could not explain his resilience. Without his entrepreneurial imagination -his recognition of heritage-inspired coffins as a potentially viable market that could replace the then-dying tourist carving market-Pak Tandi's atelier would have folded, as was the fate of other souvenir carvers' workshops in this era.

As suggested earlier, Pak Tandi's atelier's intensified carving efforts and return to carvers' oldest traditional customer base- the local communitymight be seen as a kind of "artistic involution." (Now that tourism has rebounded, Pak Tandi's atelier continues to concentrate most heavily on the local ritual market, which has proven to be a wise choice, as the tourist taste for carved wall plaques and trays seems to have abated). But, this level of success with "artistic involution" is relatively rare. Pak Tandi's combination of creative capacity for invention and improvisation (Bourdieu, 1990) and his access to economic social, cultural, and political capital, all helped fuel his success at weathering the tourism drought. $^{9}$

A gender-attuned framework requires that we also ask how female Toraja responded to these shifts. The next two sections spotlight the ways in which female Torajan microentrepreneurs and handicraft makers responded to the ebbs and flows in tourism.

\section{Example 2: "These Days Domestic Tourists Don't} Like Carvings, They Like Bags”: Helping Struggling Rural Women Sew Their Way to Economic Independence

Changes in the types and tastes of tourists arriving in the Toraja highlands set the backdrop for my second example. The dwindling numbers of international tourists in the 2000s was acutely felt by male souvenir carvers and their families, because foreign tourists had been the primary market for more substantial wooden souvenirs. ${ }^{10}$ For some years, when international tourist arrivals were at their lowest, the primary tourists arriving in much smaller numbers were either domestic tourists or migrant Torajans (who combined return visits to the homeland with touristic activities). These Indonesian tourists had less interest in carvings: instead, they were drawn to textiles and T-shirts. ${ }^{11}$ One tourist stall owner whose husband occasionally dabbled in carving handcrafts summed it up, "These days domestic tourists don't like carvings, they like bags."

Some Toraja women from middle class or aristocratic families with links to Ke'te' Kesu village drew on their creativity, savings, sewing machines, and networks to engage with the shift in tourist desires. These women had sufficient resources to purchase loom-woven Toraja textiles produced in the northern weaving area of Sa'dan. Selecting Toraja textiles with more contemporary (rather than ethnic) patterns, they craft new souvenir lines, affixing their own Toraja-themed labels and offering them for sale in Rantepao shops or in stalls in villages frequented by tourists. Those who live adjacent to tourist-oriented villages also routinely study the bags toted by tourists for design inspiration.

A few of the younger, more successful female microentrepreneurs had studied or worked in Indonesian cities such as Jakarta or Makassar, where they acquired an appreciation for contemporary urban fashion. These younger women now produce stylish handbags, laptop cases, and toiletry bags that sell briskly to domestic tourists. In the months when domestic tourists are scarce, they use their cell phones to find new markets, posting photographs of their latest handbag creations on Facebook, and inviting interested buyers to contact them. These women actively cultivate new Facebook "friends" with an eye to growing their cyber markets. As Indonesia has the third-largest Facebook presence in the world ${ }^{12}$, this electronic market offers them a new, alternative source of revenue. However, it pays to underscore that their success was not only dependent on their abilities to combine sewing skills with creative innovations: their success hinged on their understanding of urban fashion sensibilities. Thus, those who were most resilient in the face of tourism's unpredictability were women who had not only some economic capital at the outset, as well as social capital (in the form of a vast network of Facebook friends with disposable incomes), but also cultural capital (in the form of urban experiences, and a welltrained eye for fashion). 
I turn now to profile one 60-year-old woman, who channeled these varied resources into her handicraft stall at Ke’te' Kesu village. Mama Lina, the daughter of a famed aristocrat, had married into Ke'te' Kesu's leading family. Although both Mama Lina and her husband owned rice fields, they supplemented this income with other work. Over the course of his life, her husband had varied jobs in the tourism sector: as a younger man he had worked as a trekking guide, and later became involved in a white-water rafting business. Mama Lina reared several children while enjoying a career in public service. When I first met her in the 1980s, she was working at the managerial-level at the government Family Planning Office and subsequently went on to become the head government official (Camat) of a Northern Toraja district. In preparation for their retirement, the couple erected a small, tidy souvenir shop on the pathway into Ke'te' Kesu village. In the 1990s, when tourism was booming, tourist-oriented shops and stalls had mushroomed around the village. Although many had gone under in the lean years of the 2000s, by the time their shop opened domestic tourism was enjoying a renaissance: Mama Lina and her husband's small shop became one of many competing, family-run microenterprises. When I visited in 2017, it was clear that the couple was pouring energy into finding creative ways to attract business in a climate of stiff competition. ${ }^{13}$

One line of new textile creations (kreasi baru) was flying off the shelves: an assortment of Toraja textile bags designed by Mama Lina's daughter, an electrical engineer who enjoyed sewing and was currently rearing young children in Jakarta. Mama Lina's daughter spent her spare moments designing fashionable bags from Toraja textiles and e-mailing the designs to her mother. Mama Lina, in turn, hired village women to sew her daughter's designs, which she then sold in her handicraft shop. Domestic tourists' shift in souvenir tastes, away from carvings created by males towards textile goods sewn by rural females, was clearly benefitting a new cohort of village-based women. As Mama Lina told me,

In the old days, village women stayed home and took care of the household, but these days they can sew and bead purses to sell to tourists. This helps women deal with naughty (nakal) ${ }^{14}$ husbands who do nothing but sit around gambling and don't contribute [to the family's well-being]. Sewing purses for tourists gives them a way to save and take care of themselves and their families.

Mama Lina explained that in addition to hiring local women to sew bags for her shop, she had deliberately sought out some of the most "at-risk" women-single mothers or women with notoriously irresponsible gambler husbands, and suggested they gather at her shop, along with their infants and young children, and learn to sew handbags for tourists. Mama Lina gives them the necessary materials (cloth, thread, zippers, etc.), use of the souvenir shop's sewing machine, and enough capital to get started. They sew items to sell at the Rantepao market on market day (where local shop owners often seek their wares). When these at-risk women are gathered together in her souvenir shop, Mama Lina urges them to consider saving and participating together in informal rotating loans (arisan). Today, many of these impoverished rural women have improved their lives: One has replaced her dirt floor with a new tile floor, and others have rebuilt their modest homes. In short, via these contemporary handbags crafted from Toraja textiles, some once desperately poor women are gaining new economic independence.

Of course, it pays to note that without a community-oriented benefactress, these women would have neither the capital nor the materials necessary to make these strides towards economic resilience. This raises questions pertaining to strategies pursued by female tourates who lack access to economic, cultural, and social capital. How do they "make do" (de Certeau, 1984) in the face of tourism unpredictability? I turn now to offer a final example of the slower, yet promising, path pursued by one village woman.

Example 3: "People Like to Snack ... and We Can Eat What Doesn’t Sell”: Mama Erne’s Edibles

Mama Erne is a striking woman in her 40s. As a young and bright teen, she had worked as a "helper" in the household of an aristocratic family in Ke'te' Kesu village, earning lodging and a modest salary while attending high school. A pregnancy and marriage obliged her to abandon her schooling and to assume adult responsibilities earlier than most. Economically, life was precarious for many years, 
as she and her husband reared their children, toiled at subsistence farming, and tried to scrape together enough cash to pay for their children's' elementary and middle schooling. On a small plot of land adjacent to her modest platform home, Mama Erne grows leafy greens for pigs, which she sells to local families, along with small quantities of cooking gas. This earns her just enough to tend to her family's basic needs.

Mama Erne's home is within walking distance of Ke'te' Kesu, tantalizingly close to opportunities for enrichment via the tourism economy (when it is thriving). But Mama Erne lacked the capital to invest in a tourist stall and the artisanal and sewing skills to produce touristic mementos. Moreover, even if she could acquire these skills, she was without funds to invest in the raw materials to craft souvenirs. Instead, drawing on her gendered skills in cooking, Mama Erne decided to try her hand at producing rice-based snacks to sell to the local guides and drivers of tourist vans idling in the parking lot outside Ke'te' Kesu. She began on a minuscule scale, using ingredients she had on hand at home-a little rice, coconut milk, and a few tomatoes and chili pepper-to make a small batch of sticky rice snacks. Explaining her reasoning to me, she said, "People like to snack, and if they don't [buy], we can always eat what doesn't sell." The snacks sold, and slowly she was able to save enough to make greater quantities, which she started selling to domestic tourists and local tourates on busier holiday weekends.

When I reencountered her during a 2017 Music Festival in Ke'te' Kesu, Mama Erne was perched on a cement step near the village's ticket booth, with a cloth-covered plastic bin brimming with her savory rice snacks. In anticipation of the festival, she had worked late making extra batches, which she sold for IDR 5,000 each (roughly 37 cents). Although she had to compete with several coffee and snack stands (which offered accouterments she did not have-benches, napkins, and plastic spoons), Mama Erne's pricing was competitive, and her freshly cooked snacks appealed to locals. Over the course of the music festival, she sold 30 little rice snack bundles to local tourates, musicians, and even a few domestic tourists. She was clearly pleased and had already calculated that, after deducting for expenses, her efforts would enable her to pocket IDR 60,000 (US\$4.41). Although a modest sum compared to the US\$11.03 per day earned by carvers in Pak Tandi's workshop, for Mama Erne the extra income afforded her a greater degree of economic stability. Although she lacked the various forms of capital possessed by other microentrepreneurs profiled here, her ability to recognize a potential economic niche in the tourism-oriented arena (drivers and local tourates, initially), in tandem with her gendered cooking skills, enabled her to make slow, gradual progress towards economic security.

\section{Discussion}

In keeping with calls for further research on the nature of resilience in tourism destinations (e.g., Bec et al., 2016), this qualitative study has spotlighted individual tourates' strategies for achieving economic resilience in the face of dramatic ebbs and flows in tourism. These ethnographically grounded, closely hewn case studies offer nuanced understandings of the ways in which individuals draw on their cultural knowledge, gendered practices, and often-limited resources in attempts to navigate tourism's increasingly unpredictable market. Such an individual-focused approach complements broader studies accentuating regional or community-wide resilience. As this study has highlighted, individuals' strategies for "making do" (de Certeau, 1984) and "responding to life's contingencies in creative ways" (Bruner, 2005) are dependent on a variety of factors including, yet extending well beyond, the ability to imagine new markets and products to replace tourist markets when tourist markets recede. Access to various forms of capital (economic, social, or cultural) figures into tourates' abilities to successfully achieve a measure of economic security, as do culturally gendered patterns in the distribution of skills and expectations pertaining to responsibilities.

The implications of this research are multiple. Political tumult, climate change, and natural disasters are likely to continue to challenge the adaptive capacities of those residing in, and making a living from, tourist destinations. This is all the more the case for island destinations (cf. Cheer, Cole, Reeves, \& Kato, 2017). If tourism policy makers and planners are to successfully address these challenges, 
more studies spotlighting individuals (such as those featured here), in tandem with broader communityfocused studies, can help identify foundations on which resilience strategies can be built.

\section{Notes}

${ }^{1}$ Some exceptions include Ruiz-Ballesteros' (2010) study of socioecological resilience and community-based tourism in Agua Blanca, Ecuador, and Espiner and Becken's (2013) study of stakeholder perceptions and responses to threats to glacier tourism in two New Zealand communities, although the latter draws primarily on survey data culled from 24 stakeholders and is neither ethnographic nor longitudinal.

${ }^{2}$ As various scholars have noted, social capital cannot be assumed to be constant. Under some circumstances, it may enhance one's access to resources, whereas in other circumstances it may prove a hindrance (Ferguson et al., 2017; Kwon \& Adler, 2014).

${ }^{3}$ Tana Toraja Regency was split into two separate regencies in 2008 (Klenke, 2013).

${ }^{4}$ This return to farming parallels Causey's (2007) report on Batak carvers' reactions to tourism's decline in this era, as well.

${ }^{5}$ In 2011, the number of foreign and domestic tourist arrivals in Tana Toraja totaled 19,325 (Data from the Tana Toraja Culture and Tourism Office-3,674 foreign tourists and 12,631 domestic tourists). This 2011 figure is significantly below the figures for the mid-1990s, when annual foreign tourist visits ranged between 40,000 and 59,000 and domestic tourist visits were reported as ranging between 152,000 to 204,000 annually (note some problems with the domestic tourist data).

${ }^{6}$ These findings parallel Andrew Causey’s (2007) reports on the transformations in the once-touristic region of the Toba Batak in Sumatra. However, in Toraja those carvers from families of means who could afford to do so, threw themselves into family ritual activities, a more traditional arena for enhancing status and local prestige.

${ }^{7}$ All of the names in this article are pseudonyms.

${ }^{8}$ By 2017 there were some half-dozen tourist stalls at the village entrance gate, and still more aligning the road into and beyond the village itself. Today, most of these stalls hawk textiles, t-shirts, and coffee, rather than carvings.

${ }^{9}$ It is worth noting that Pak Tandi's reorientation of his atelier away from the unpredictable tourism market and towards the more reliable and profitable local market has provided employment and a degree of security for handicraft carvers from his community. His endeavors are couched in language that stresses the importance of not only individual but community well-being. However, this case of economic resilience in the context of waning tourism also echoes the patterns reported in other studies addressing community tourism-based development: these studies found elite kin groups' social capital enabled "capture” of indigenous tourism income/benefits projects (See Schilcher, 2007; Taylor, 2017).
${ }^{10}$ Small wooden keychains were the exception: these sold well with domestic tourists, who tended to buy them in bulk as gifts for friends, family members, and classmates.

${ }^{11}$ Torajans cite various reasons for domestic tourists' disinterest in carved souvenirs. Some observe that the rising prices of wood due to the depletion the most desirable woods in the late 1990s and 2000s meant that the wood used by carvers in the 2000s was too young and warped easily, which visitors recognized. Others suggested that the Indonesian tradition of extensive gift giving upon return from vacations meant that larger and heavy wooden carvings were too cumbersome to be desirable as purchases. Based on my own observations, I suspect that an additional factor was that carved trays and wall plaques simply did not mesh with most urban Indonesian tastes in home décor. As Cohen's (2000) research on commercialized crafts in Thailand suggests, in order to find markets, ethnic arts must resonate with purchasers' conceptions of identity and tastes.

${ }^{12}$ See "Leading countries based on numbers of Facebook users as of January 2018” https:/www.statista.com/ statistics/268136/top-15-countries-based-on-number-offacebook-users/

${ }^{13}$ For instance, on the opening day of a much-touted 2017 music festival in the village, Mama Lina’s husband decided to set up a manikin clothed in traditional Toraja attire alongside a sign (in both Indonesian and English) inviting tourists to rent the traditional attire for souvenir photos. I encountered him as he was setting up the display and he sought my feedback on the grammar in the English portion of the sign. We chatted about the new display, and he explained with excitement that this was something no one else in the village was doing. Thus, he hoped it would draw tourists into the shop. As he said, even if tourists did not rent the traditional clothing, they might spot something else to buy. At the end of the day, he reported that several Indonesian tourists had rented the clothing for souvenir photographs, and deemed the experiment a success.

${ }^{14}$ Nakal translates as "naughty" but covers a wide range of behavior, ranging from minor childish tantrums to more serious infractions, including gambling, cheating, and drunkenness.

\section{References}

Adams, K. M. (2006). Art as politics: Re-crafting tourism, identities and power in Tana Toraja, Indonesia: Honolulu, Hawaii: University of Hawai'i Press.

Adams, K. M. (2012). Ethnographic methods. In L. Dwyer, A. Gill, \& N. Seertaram (Eds.), Handbook of research methods in tourism: Qualitative and quantitative methods (pp. 339-351). Northampton, MA: Edward Elgar/ Ashgate.

Aditjondro, G. (2010). Pragmatisme. menjadi to 'sugi dan to kapua di Toraja: Dominasi Aristokrasi dalam oligarki bisnis, politik dan gereja. Yogyakarta, Indonesia: CV Gunung Sopai Press.

Aitchison, C. (2005). Feminist and gender perspectives in tourism studies: The socio-cultural nexus of critical and cultural theories. Tourist Studies, 5(3), 207-224. 
Aitchison, C. (2009). Gender and tourism discourses: Advancing the gender project in tourism studies. In J. Tazim \& M. Robinson (Eds.), The Sage handbook of tourism studies (pp. 631-643). London, UK; Los Angeles, CA: Sage.

Adler, P. A. \& Adler, P. (1994). Observation technique. In N. K. Denzin \& Y. S. Lincoln (Eds.), Handbook of qualitative research (pp. 377-392). Thousand Oaks, CA: Sage.

Bakas, F. E. (2017). Community resilience through entrepreneurship: The role of gender. Journal of Enterprising Communities: People and Places in the Global Economy, 11(1), 61-77.

Bec, A., McLennan, C., \& Moyle, B. (2016). Community resilience to long-term tourism decline and rejuvenation: A literature review and conceptual model. Current Issues in Tourism, 19(5), 451-457.

Bernard, H. R. (2006). Handbook of methods in cultural anthropology: Qualitative and quantitative methods. Lanham, MD: Alta Mira Press.

Bourdieu, P. (1977). Outline of a theory of practice. Cambridge, UK: Cambridge University Press.

Bourdieu, P. (1984). Distinction: A social critique of the judgment of taste [Translated by R. Nice]. Cambridge, MA: Harvard University Press.

Bourdieu, P. (1986). The forms of capital. In J. Richardson (Ed.), Handbook of theory and research for the sociology of education (pp. 241-258). New York, NY: Greenwood.

Bourdieu, P. (1990). The logic of practice (R. Nice, Trans.). Palo Alto, CA: Stanford University Press.

Bras, K., \& Dahles, H. (1999). Massage, Miss? Women entrepreneurs and beach tourism in Bali. In H. Dahles \& K. Bras (Eds.), Tourism and small entrepreneurs: Development, national policy, and entrepreneurial culture: Indonesian cases (pp. 35-51). New York, NY: Cognizant Communication Corporation.

Bruner, E. (1993). Epilogue. In S. Lavie, K. Narayan, \& R. Rosaldo (Eds.), Creativity/anthropology (pp. 321-334). Ithaca, NY: Cornell University Press.

Bruner, E. (2005). Culture on tour: Ethnographies of travel. Chicago, IL: Bibliovault OAI Repository, the University of Chicago Press.

Bureau of Statistics. (2015). Toraja Utara Regency in figures 2015. Publication Number 73260.1601. Rantepao, Indonesia: Badan Pusat Statistik Kabupaten Toraja Utara.

Causey, A. (2003). Hard bargaining in Sumatra: Western travelers and Toba Bataks in the marketplace of souvenirs. Honolulu, Hawaii: University of Hawai'i Press.

Causey, A. (2007). "Go back to the Batak, it's safe there”: Tourism in north Sumatra during perilous times. Indonesia and the Malay World, 35(103), 257-271.

Cheer, J., Cole, S. Reeves, K., \& Kato, K. (2017). Tourism and islandscapes: Cultural realignment, social-ecological resilience and change. Shima Journal, 11(1), 40-53.

Cheer, J., \& Lew, A. (2017). Tourism resilience and sustainability: Adapting to social, political, and economic change. London, UK: Routledge.
Cochrane, J. (2010). The sphere of tourism resilience. Tourism Recreation Research, 35(2), 173-185.

Cohen, E. (2000). The commercialized crafts of Thailand: Hill tribes and lowland villages. Honolulu, Hawaii: University of Hawaii Press.

Cole, S. (2004). Shared benefits: Longitudinal research in Eastern Indonesia. In J. Phillimore \& L. Goodson (Eds.), Qualitative research in tourism: Ontologies, epistemologies and methodologies (pp. 292-310). Abingdon, UK: Routledge.

de Certeau, M. (1984). The practice of everyday life (S. Rendall, Trans.). Berkeley, CA: University of California Press.

Ellen, R. F. (1984). Ethnographic research. London, UK: Academic Press Inc.

Espiner, S., \& Becken, S. (2013). Tourist towns on the edge: Conceptualising vulnerability and resilience in a protected tourism system. Journal of Sustainable Tourism, 22(4), 646-665.

Fairclough, N. (1995). Critical discourse analysis. Boston, MA: Addison Wesley.

Figueroa-Domecq, C., Pritchard, A., Segovia-Pérez, M., Morgan, N., \& Villacé-Molinero, T. (2015). Tourism gender research: A critical accounting. Annals of Tourism Research, 52, 87-103.

Furguson, J. Dahles, H., \& Prabawa, T. (2017). The Indonesian tourism industry under crisis: A Bourdieuan perspective on social boundaries among small-scale business owners. Asia Pacific Business Review, 23(2), 171-191.

Geertz, C. (1963). Agricultural involution: The processes of ecological change in Indonesia. Berkeley, CA: University of California Press.

Ghodsee, K. (2005). The Red Riviera: Gender, tourism and postsocialism on the Black Sea. Durham, NC: Duke University Press.

Graburn, N. (1976). Ethnic and tourist arts: Cultural expressions from the fourth world. Berkeley, CA: University of California Press.

Hall, M., Prayag, G., \& Amore, A. (2018). Tourism and resilience: Individual, organizational and destination perspectives. Bristol, UK: Channel View Publications.

Hall, D. Swain, M. B., \& Kinnaird, V. (2003). Tourism and gender: An evolving agenda. Tourism Recreation Research, 28(2), 7-11.

Henderson, J. C. (2003). Terrorism and tourism: Managing the consequences of the Bali bombings. Journal of Travel and Tourism Marketing, 15, 41-58.

Hitchcock, M. (2010). Tourism and total crisis in Indonesia: The case of Bali. Asian Pacific Business Review, 8(2), 101-120.

Hitchcock, M., \& Putra, I. N. D. (2007). Tourism, development and terrorism in Bali. Burlington, VT: Ashgate.

Hollinshead, K. (2004). Ontological craft in tourism studies: The productive mapping of identity and image in tourism settings. In J. Phillimore \& L. Goodson (Eds.), Qualitative research in tourism: Ontologies, epistemologies and methodologies (pp. 83-101). Abingdon, UK: Routledge. 
Klenke, K. (2013). Whose adat is it? Adat, indigeneity and social stratification in Tana Toraja. In Hauser-Schäublin, B. (Ed.), Adat and indigeneity in Indonesia: Culture and entitlements between heteronomy and self-ascription (pp. 149-165). Göttingen, Germany: Universitätsverlag Göttingen.

Kuo, H., Chen, C. C., Tseng W. C., Ju, L. F., \& Huang, B. W. (2008). Assessing impacts of SARS and Avian Flu on international tourism demand to Asia. Tourism Management, 29(5), 917-928.

Kwon, S., \& Adler, P. (2014). Social capital: Maturation of a field of research. Academy of Management Review, 39(4), 412-422.

Lew, A. (2014). Scale, change and resilience in community tourism planning. Tourism Geographies, 16(1), 14-22.

Little, W. (2008). Living with the Mundo Maya Project: Strategies of Maya handicraft vendors. Latin American Perspectives, 35(3), 87-102.

Morrell, E. (2005). Securing a place: Small-scale artisans in modern Indonesia. Ithaca, NY: Cornell Southeast Asia Program Publications.

Orchiston, C., Prayag, G., \& Brown, C. (2016). Organizational resilience in the tourism sector. Annals of Tourism Research, 56, 145-148.

Pelto, P. (2017). Applied ethnography: Guidelines for field research. Abingdon, UK: Routledge.

Portes, A., \& Sensenbrenner, J. (1993). Embeddedness and immigration: Notes on the social determinants of economic action. The American Journal of Sociology, 98(6), 320-350.
Prayag, G. (2017). Symbiotic relationship or not? Understanding resilience and crisis management in tourism. Tourism Management Perspectives, 25, 133-135.

Pritchard, A., Morgan, N., Ateljevic, I., \& Harris, C. (Eds.). (2007). Tourism and gender: Embodiment, sensuality and experience. Cambridge, UK: CABI.

Ruiz-Ballesteros, E. (2011). Socio-ecological resilience and community-based tourism: An approach from Agua Blanca, Ecuador. Tourism Management, 32, 655-666.

Schilcher, D. (2007). Growth versus equity: The continuum of pro-poor tourism and neoliberal governance. Current Issues in Tourism, 10(2-3), 166-193.

Strickland-Munro, J., Allison, H., \& Moore, S. (2010). Using resilience concepts to investigate the impacts of protected area tourism on communities. Annals of Tourism Research, 37(2), 499-519.

Taylor, S. (2017). Issues in measuring success in communitybased indigenous tourism: Elites, kin-groups, social capital, gender dynamics and income flows. Journal of Sustainable Tourism, 25(3), 433-439.

Volkman, T. (1985). Feasts of honor: Ritual and change in the Toraja highlands. Chicago, IL: University of Illinois Press.

Waterson, R. (2009). Paths and rivers: Sa'dan Toraja society in transformation. Leiden, The Netherlands: KITLV Press.

Waterton, E. (2009). Sights of sites: Picturing heritage, power and exclusion. Journal of Heritage Tourism, 4(1), 37-56. 
Copyright of Tourism Culture \& Communication is the property of Cognizant, LLC and its content may not be copied or emailed to multiple sites or posted to a listserv without the copyright holder's express written permission. However, users may print, download, or email articles for individual use. 